\title{
Effect of picloram herbicide on physiological responses of Eupatorium adenophorum Spreng
}

\author{
Xiaowen Liu', ${ }^{1,2}$ Chengmei Qi ${ }^{2}$, Zongcheng Wang ${ }^{2}$, Yuan $\mathrm{Li}^{1}$, Qiuxia Wang1, Meixia Guo ${ }^{1}$, \\ and Aocheng $\mathrm{Cao}^{{ }^{*}}$
}

Eupatorium adenophorum Spreng., a major invasive weed in southwestern China, has caused great economic losses. In order to find a new herbicide to control E. adenophorum, experiments were conducted to study its physiological and biochemical responses to low and high doses of picloram herbicide (4-amino-3,5,6-trichloropyridine-2-carboxylic acid). Electrolyte leakage, malondialdehyde, and free proline were stimulated by picloram, showing a remarkably increase $(p<0.05)$ with high herbicide concentration $\left(60,120\right.$, and $240 \mathrm{~g}$ ai ha $\left.^{-1}\right)$. The treated plants exhibited lower osmotic adjustment capacity, high dosage lipid peroxide levels and more free-proline accumulation. It was found that low doses $\left(12\right.$ and $24 \mathrm{~g}$ ai ha $\left.{ }^{-1}\right)$ of picloram initially increased catalase, peroxidase, superoxide dismutases and protein, but these indicators decreased $(p<$ 0.05 ) with the increase of treating time (after $3 \mathrm{~d}$ ) and dose (120 and $240 \mathrm{~g}$ ai ha $\left.{ }^{-1}\right)$. In addition, the structures of chloroplasts and mitochondria were seriously deformed. These results indicated E. adenophorum can improve its herbicide-tolerance by increasing the antioxidative system activity at the initial period of low picloram stress. However, this protective function disappeared with increasing of treating time and picloram dosage. Eupatorium adenophorum responded differently to low and high concentrations of picloram and ultrastructural changes are an important cause of death in E. adenophorum.

Key words: Picloram, Eupatorium adenophorum, response of physiology and biochemistry.

\section{INTRODUCTION}

As one of the worst invasive weeds in the world, Eupatorium adenophorum Spreng. was introduced into Yunnan province from the China-Myanmar border in the 1940s (Song et al., 2010). It is now widely distributed in Yunnan, Guizhou, Sichuan, Guangxi, and Xizang (Wei et al., 2011). Due to the fast spreading, the weed has caused significant damage to the ecological environment, economic development, and human health (Zheng et al., 2009). Chemical control of E. adenophorum was effective using herbicides such as glyphosate aqueous solution (Zhang et al., 2005), sulfometuron-methyl soluble powder (Huang et al., 2001), and picloram (Cao et al., 2006; Li et al., 2008). Picloram (4-amino3,5,6-trichloro-2-pyridinecarboxylic acid) is a systemic chlorinated herbicide, known as a synthetic auxin. This herbicide is widely used in many countries because of the high efficiency in the control of broadleaf weed and

${ }^{1}$ Institute of Plant Protection, Chinese Academy of Agricultural Sciences, Beijing, 100193, China. *Corresponding author(caoac@ vip.sina.com).

${ }^{2}$ Hunan University of Science and Engineering, Life Science \& Chemical Engineering Department, Yongzhou, 425199, China.

Received: 26 March 2014.

Accepted: 13 July 2014.

doi: $10.4067 /$ S0718-58392014000400010 woody plants in pasture, wheat, rice, barley, sugarcane, and other crop fields (Sheley et al., 2002; Nelson and Lym, 2003; Dos Santos and Masini, 2007). As a selective herbicide, many researchers have studied its mechanisms of action on plants (Ortega and Pearson, 2011; Smitha and Nair, 2011). Foy and Penner (1965) considered that its biochemical mechanisms may suppress plant respiration; while other researchers (Owens, 1969; Chang and Foy, 1982) held that its mechanism was effected by chelating free or bonded metal-ion (such as $\mathrm{Fe}^{2+}, \mathrm{Cu}^{2+}$, and $\mathrm{Mn}^{2+}$ ), and inhibiting protein synthesis such as catalase (CAT) and peroxidase (POD). However, which physiologicalbiochemical indexes of E. adenophorum was changed under picloram herbicide stress? How did they change? Solving these problems is very important for the chemical control of E. adenophoram and there were seldom reports about those changes in weeds after herbicide treatment. So it was studied that the effect of picloram herbicide on the physiological responses of E. adenophorum during early period after treating with the picloram.

\section{MATERIALS AND METHODS}

Experiments were carried out in an artificial climate laboratory of Xichang College in Sichuan province, China. In May 2009, mature E. adenophorum seeds were collected from several native habitats in Southwestern 
China (Xichang, $101^{\circ} 49^{\prime}$ E, $27^{\circ} 38^{\prime}$ N; 2000-2200 m a.s.1.) Seeds were kept dry, stored in a plastic box, and labeled for identification. The selected seeds were sown in pots containing soil from the experimental field of Xichang College. The soil pH was 7.7 in $1 \mathrm{M} \mathrm{CaCl}_{2}, 6.3$ in water and the soil contained $1.13 \%$ of organic $\mathrm{C}$. The pots were at $25 \pm 2{ }^{\circ} \mathrm{C}$ and $55 \pm 8 \%$ relative humidity under a 16:8 $\mathrm{h}$ photoperiod, with light supplied at a photon flux density of $420 \pm 50 \mu \mathrm{mol} \cdot \mathrm{m}^{-2} \cdot \mathrm{s}^{-1}$ and $\mathrm{CO}_{2}$ concentration of 450 $\pm 50 \mu \mathrm{mol} \cdot \mathrm{mol}^{-1}$. The pots were periodically irrigated in order to keep the soil at field capacity and prevent water stress in the plants. After $6 \mathrm{wk}$, the healthy plantlets were foliage sprayed with picloram $24 \%$ aqua (Lier chemical, Mianyang, Sichuan, China) at 0 (control), 12, 24, 60, 120, and $240 \mathrm{~g}^{\text {ai ha }}{ }^{-1}$ (CK, P12, P24, P60, P120, and P240, respectively) (general picloram concentration is $24 \sim 48$ $\mathrm{g}$ ai ha ${ }^{-1}$ for application into the agricultural field). Each treatment had five replicates, and each replicate consisted of five plantlets. Seedlings were planted on experimental pots on 25 April 2010, and samples were harvested at 1, 3,5 , and $7 \mathrm{~d}$ after treatment during the summer season.

\section{Determination of membrane permeability and lipid peroxidation}

The membrane permeability of the crop was determined by measuring frequency-dependent electrical conductivity. Fresh leaves $(0.2 \mathrm{~g})$ were rinsed twice in distilled water and then incubated in $30 \mathrm{~mL} 0.3 \mathrm{M}$ mannitol solution at $25^{\circ} \mathrm{C}$ with shaking for $30 \mathrm{~min}$. Electrolyte leakage was measured with a conductivity meter (Model DDS11A, Shanghai Scientific Instruments, Shanghai, China). Electrolyte leakage was determined after boiling a duplicate batch of fresh leaves for $30 \mathrm{~min}$ and then cooling to $25{ }^{\circ} \mathrm{C}$. Relative leakage (RL) was expressed as a proportion $(\%)$ of total electrolyte leakage (EL). The level of lipid peroxidation was measured in terms of total malondialdehyde (MDA) contents and the reaction reagent consisted of $0.4 \mathrm{~N}$ trichloroacetic acid (TCA) $+19.68 \mathrm{~mL}$ of distilled water $+0.4 \mathrm{~mL} \mathrm{HCl}+100 \mathrm{mg}$ 2-thiobarbituric acid (TBA). Prepared leaf extract (in phosphate buffer) was added to the reaction reagent and absorbance was taken at $532 \mathrm{~nm}$; MDA contents were calculated as followed:

\section{Concentration of MDA $=$ Absorbance $\times 6.45 \mathrm{~mL} \mathrm{mg}^{-1} \mathrm{FW}$}

\section{Proline and soluble protein measurements}

Proline was determined by the ninhydrin method (Manna et al., 2006). Fresh leaves $(0.3 \mathrm{~g})$ were homogenized in 6 $\mathrm{mL}$ of $3 \%$ sulfosalicylic acid solution. After centrifugation, $2 \mathrm{~mL}$ supernatant, $2 \mathrm{~mL}$ glacial acetic acid and $2 \mathrm{~mL}$ $2.5 \%$ acid ninhydrin solution were added to a test tube and covered with a Teflon cap. The absorbance of the free proline concentration was measured at $520 \mathrm{~nm}$. The proline concentration was expressed as $\mathrm{mg} \cdot \mathrm{g}^{-1} \mathrm{FW}$. The soluble protein was measured according to the Coomassie brilliant blue G250 method (Li, 2002). The soluble protein content was measured by a spectrophotometer at $595 \mathrm{~nm}$.

\section{Antioxidant enzyme assay}

Fresh seedling leaves ( $1 \mathrm{~g}$ ) were homogenized with a mortar and pestle using liquid nitrogen in 10 mLextraction buffer $(20 \mathrm{mM}$ Tris- $\mathrm{HCl}$ in $1 \%$ polyvinylpyrrolidone, $\mathrm{pH}$ 7.4). The detailed methods were illustrated by Polle et al. (1997). After filtration through two layers of gauze to remove any debris, the homogenate was centrifuged at $10000 \times \mathrm{g}$ for $20 \mathrm{~min}$. The supernatant was used for both the enzyme activity and some other assay. The Coomassie Brilliant Blue G-250 method was used to quantify the enzyme content. Superoxide dismutase (SOD) was determined on the basis of its ability to inhibit the photochemical reduction of nitro blue tetrazolium (Beauchamp and Fridovich, 1971). The reaction solution contained $50 \mathrm{mM}$ phosphate buffer $(\mathrm{pH} 7.8)$, $13 \mathrm{mM}$ methionine, $75 \mu \mathrm{M}$ nitro blue tetrazolium, $2 \mu \mathrm{M}$ riboflavin, $100 \mathrm{nM}$ EDTA, and dd $\mathrm{H}_{2} \mathrm{O}$. The riboflavin was added last. The reaction mixture was read at $560 \mathrm{~nm}$. One unit of SOD activity (U) was designated as the amount of enzyme that caused $50 \%$ inhibition of initial reaction rate; SOD activity used $\mathrm{U} \mathrm{g}^{-1} \mathrm{FW}$. Catalase (CAT) was assayed by Aebi method (Aebi, 1984). Based on $\mathrm{H}_{2} \mathrm{O}_{2}$ hydrolysis, the decreasing absorbance was measured at $240 \mathrm{~nm}$ (A240). Reduction of 0.1 at A240 in $1 \mathrm{~min}$ is

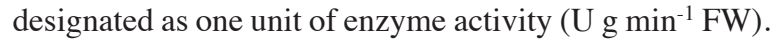
POD activity is measured by guaiacol spectrophotometry (Lagrimini, 1991). When exposed to $\mathrm{H}_{2} \mathrm{O}_{2}$, POD catalyzed the guaiacol to tetraguaiacol, which had optical density (OD) of $470 \mathrm{~nm}$. The reaction solution contained $100 \mathrm{mM}$ phosphate buffer ( $\mathrm{pH} 6.0$ ), $33 \mathrm{mM}$ guaiacol and $0.3 \mathrm{mM}$ $\mathrm{H}_{2} \mathrm{O}_{2}$. Specific activity of POD was calculated from the increase in OD470 for $30 \mathrm{~s}$ and expressed as $\mathrm{U} \mathrm{g} \mathrm{min} \mathrm{g}^{-1}$ FW.

\section{Cellular ultrastructure observation}

Transmission electron microscopy (TEM) was performed on small sections (1-2 $\mathrm{mm}$ in length) of the fifth fully expanded leaves. Leaflets were fixed with 3\% glutaraldehyde (v/v) in $0.1 \mathrm{M}$ phosphate buffer ( $\mathrm{pH} 7.2$ ) for $6-8 \mathrm{~h}$ under $4{ }^{\circ} \mathrm{C}$, postfixed in $1 \%$ osmium tetraoxide for $1 \mathrm{~h}$ and immersed in $0.1 \mathrm{M}$ phosphate buffer $(\mathrm{pH} 7.2)$ for 1-2 h. Following this, leaflets were dehydrated in a graded ethanol series $(50,60,70,80,90$, and 100\%) and embedded in epon-araldite. Ultrathin sections $(80 \mathrm{~nm})$ were sliced, stained with uranyl acetate and lead citrate and mounted on copper grids for viewing in the H-600IV transmission electron microscope (Hitachi, Tokyo, Japan) at an accelerating voltage of $60.0 \mathrm{kV}$.

\section{Statistical analysis}

A completely randomized design with five replicates was adopted. Data were presented graphically as means \pm standard errors and analyzed by the statistics analysis 
System 8.0 (SAS Institute, Cary, North Carolina, USA). Duncan test followed by a Bonferroni correction $(\mathrm{a}=$ 0.05 ) was used to detect possible differences among the treatments.

\section{RESULTS}

\section{Membrane permeability and peroxidation products}

The relative conductivity (RL) increased markedly with increasing of picloram concentration (Figure 1). In contrary to the control, RL significantly increased under picloram stress $(p<0.05)$; it first increased and then decreased with extending of treatment time. Relative conductivity reached a maximum in all picloram treatments on the $5^{\text {th }}$ day, increasing $32 \%, 36 \%, 42 \%, 43 \%$, and $44 \%$, respectively, compared to the control. However, at $7^{\text {th }} d$, the treatment groups exhibited different levels of decline. MDA continually increased with increasing picloram concentration and extending treatment time (Figure 2), and all treatments were significantly different $(\mathrm{p}<0.05)$. On the $7^{\text {th }}$ day, MDA contents were 2.23, 2.27, 2.62, 2.71, and 2.93 times compared with the control, respectively

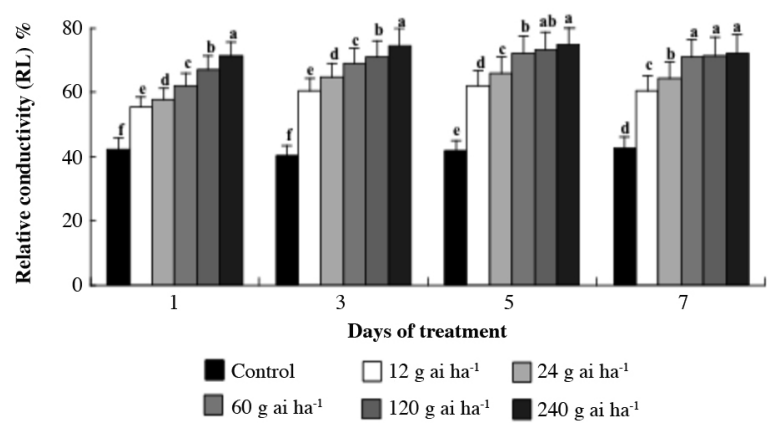

Different letters indicate the significant difference between data points $(\mathrm{p}<0.05)$.

Figure 1. Relative conductivity (RL) in leaves of Eupatorium adenophorum exposed to picloram treatments $(12,24,60,120$, and $240 \mathrm{~g}^{\text {ai }} \mathrm{ha}^{-1}$ ) for $7 \mathrm{~d}$. Values are mean $\pm \mathrm{SD}$ of five replicate measurements.

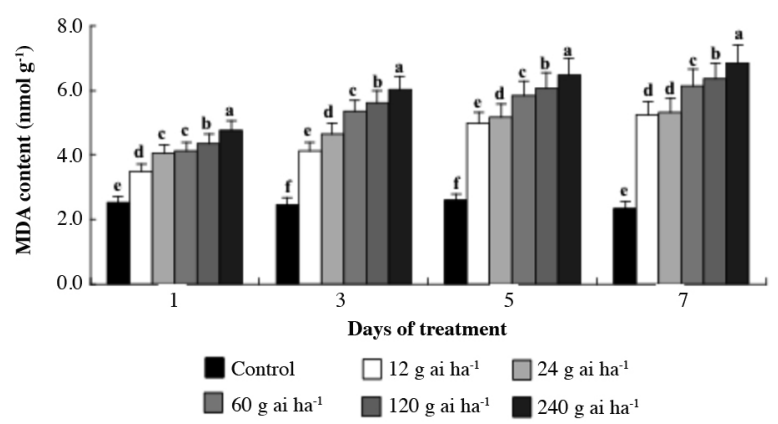

Different letters indicate the significant difference between data points $(\mathrm{p}<0.05)$.

Figure 2. Malondialdehyde (MDA) content in leaves of Eupatorium adenophorum exposed to picloram treatments $(12,24,60,120$, and $240 \mathrm{~g}^{\text {ai }} \mathrm{ha}^{-1}$ ) for $7 \mathrm{~d}$. Values are mean $\pm \mathrm{SD}$ of five replicate measurements.
(Figure 2). These indicated that cell membrane of $E$. adenophorum was severely damaged under picloram stress.

\section{Free proline and soluble proteins}

Data of free proline and soluble proteins showed that proline concentrations were significantly different under all stress conditions (Figures 3 and 4). Initially proline increased with increasing picloram concentration and extending treatment time during $3 \mathrm{~d}$ after treatment (DAT). However, from 5 to 7 DAT, the proline concentration declined in all treatments. The fall in proline concentration was modest in the low picloram treatment (P12) but was $>30 \%$ below the peak in the high dosage picloram treatments (P60, P120, and P240). The difference among dosage treatments was distinct $(\mathrm{p}<0.05)$, except 60 and $120 \mathrm{~g}$ ai ha ${ }^{-1}$ treatments (Figure 3). An alteration in soluble protein content is an important index of the degree of injury to plants under environmental stress. The low concentrations of picloram (P12 and P24) increased the soluble protein content slowly during 3 DAT, and became significantly high dosage than the control after 3 DAT

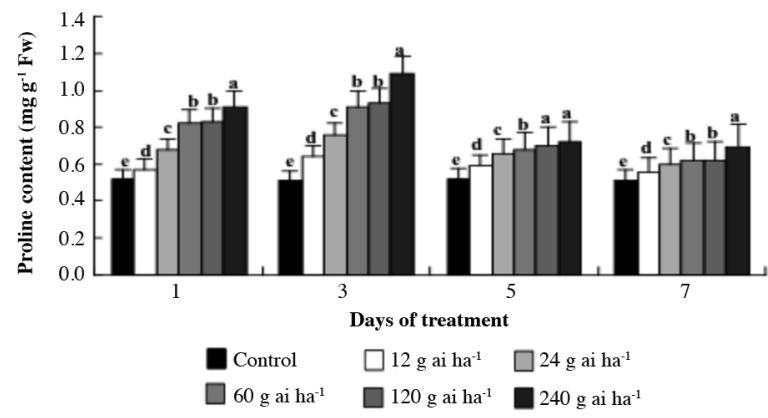

Different letters indicate the significant difference between data points $(\mathrm{p}<0.05)$.

Figure 3. Proline content in leaves of Eupatorium adenophorum exposed to picloram treatments $\left(12,24,60,120\right.$, and $\left.240 \mathrm{~g}_{\text {ai ha }}{ }^{-1}\right)$ for 7 d. Values are mean \pm SD of five replicate measurements.

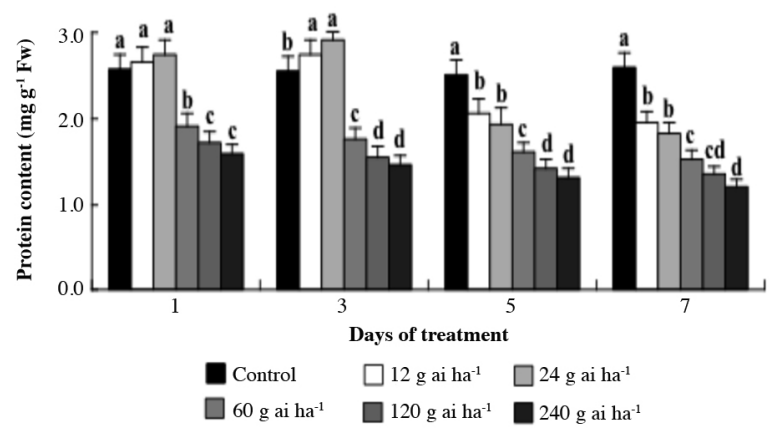

Different letters indicate the significant difference between data points $(\mathrm{p}<0.05)$.

Figure 4. Content of soluble protein in leaves of Eupatorium adenophorum exposed to picloram treatments $(12,24,60,120$, and $240 \mathrm{~g}$ ai $^{-1}$ ) for $7 \mathrm{~d}$. Values are mean \pm SD of five replicate measurements. 
$(\mathrm{p}<0.05)$. In contrast, the soluble protein significantly decreased in groups treated with high dosage picloram concentrations (P60, P120, and P240). From 5 DAT, soluble protein decreased with increasing of the herbicide concentration in all treatments. The results indicated that low picloram stress increased soluble protein synthesis for a short time, but it was inhibited significantly with extending of treatment time. Soluble protein synthesis was inhibited by high dosage concentrations of picloram (P60, P120, and P240) (Figure 4).

\section{Antioxidant enzymes}

Data of antioxidant enzymes are shown in Figures 5, 6, and 7 . The CAT activity in the treatment with different dosages picloram (P12, P24, and P60) increased initially; on the 3 DAT, the P60 treatment group showed a $7.71 \%$ increase compared to the control. However, after $3 \mathrm{~d}, \mathrm{CAT}$ activity in the three dosages of picloram treatments fell below the control significantly. The high dosage picloram treatments (P120 and P240) exhibited a different response: their CAT activity declined throughout the test period. After 7 DAT, CAT activity in P12, P24, P60, P120, and

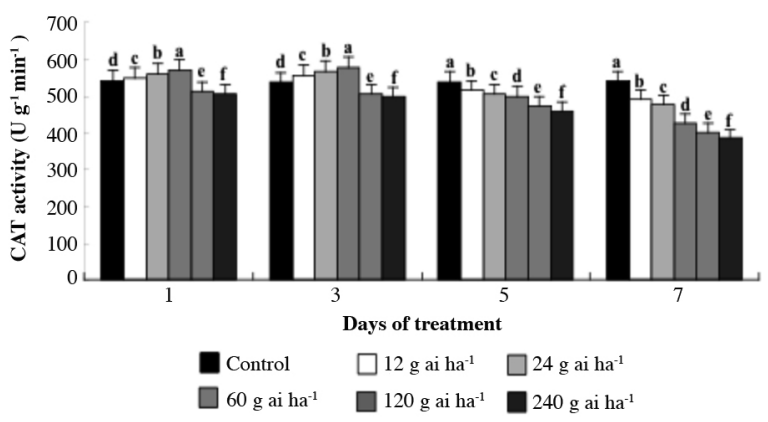

Different letters indicate the significant difference between data points $(\mathrm{p}<0.05)$.

Figure 5. Catalase (CAT) activity in leaves of Eupatorium adenophorum exposed to picloram treatments $(12,24,60,120$, and $240 \mathrm{~g}$ ai ha $\left.\mathrm{ha}^{-1}\right)$ for $7 \mathrm{~d}$. Values are the mean $\pm \mathrm{SD}$ of five replicate measurements.

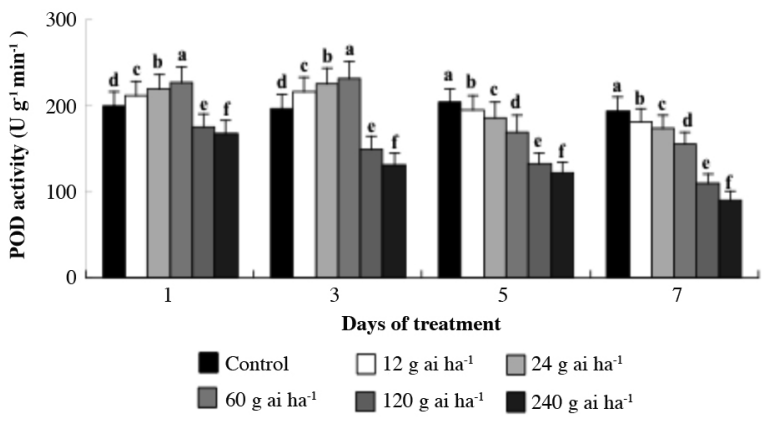

Different letters indicate the significant difference between data points $(\mathrm{p}<0.05)$.

Figure 6. Peroxidase (POD) activity in leaves of Eupatorium adenophorum exposed to picloram treatments $(12,24,60,120$, and $240 \mathrm{~g} \mathrm{ai} \mathrm{ha}^{-1}$ ) for $7 \mathrm{~d}$. Values are mean \pm SD of five replicate measurements.

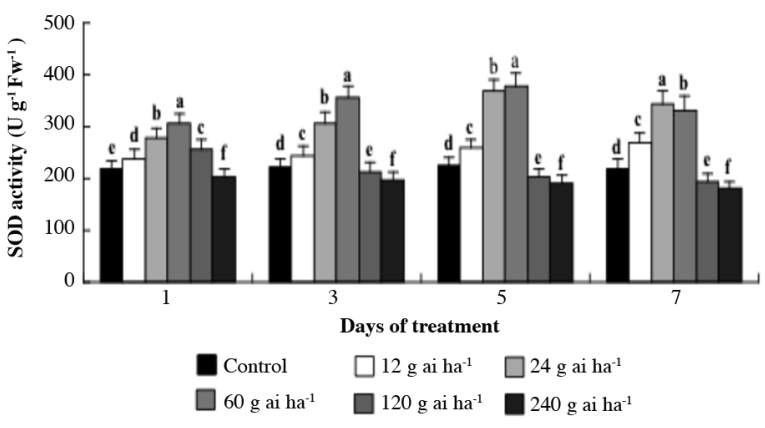

Different letters indicate the significant difference between data points $(\mathrm{p}<0.05)$

Figure 7. Superoxide dismutase (SOD) activity in leaves of Eupatorium adenophorum exposed to picloram treatments (12, $24,60,120$, and $240 \mathrm{~g}^{\mathrm{ai}} \mathrm{ha}^{-1}$ ) for $7 \mathrm{~d}$. Values are mean $\pm \mathrm{SD}$ of five replicate measurements.

P240 treatment groups had declined 9\%, 12\%, 22\%, 25\%, and $29 \%$, respectively, compared to the control (Figure 5). POD activity initially increased in three picloram treatments (P12, P24, and P60), and then declined below the control level after 3 DAT. On the 3 DAT, POD activity in the P60 treatment reached a maximum, showing $18 \%$ increase. However, POD activity in the high dosage concentrations of picloram (P120 and P240) treatments showed different: POD activity fell from the 1 DAT and continued to decline. From 5 DAT, POD activity decreased in all treatments. On the 7 DAT, POD activity continued to decline with increasing of picloram concentration, falling to $94 \%, 90 \%, 81 \%, 57 \%$, and $47 \%$, respectively, of the control level. This indicated that the tolerance of E. adenophorum to picloram was strong at low concentrations, however under high concentrations of picloram POD activity declined because of plant damage. SOD activity in the picloram treatment groups (P24 and P60) increased and peaked around day 5 DAT, followed by a slight decline (Figure 7). In the 5 DAT, SOD activity in the three dosages of picloram groups (P12, P24, and P60) increased $13 \%, 39 \%$, and $40 \%$, respectively, compared to the control. The high dosage treatment groups (P120 and P240) exhibited a different response: SOD activity fell from 1 DAT or 3 DAT, and continued to decline gradually. On 7 DAT, the P120 and P240 treatments fell to $88 \%$ and $82 \%$, respectively, of the level in the control group. The SOD activity was significant different among the treated groups $(\mathrm{p}<0.05)$.

\section{Cellular ultrastructure}

The organelles of mesophyll cells in E. adenophorum were observed to be normal under control conditions (Figure 8a, b, c), but under stress injuries on the plant resulted from picloram herbicide became apparent, especially in the chloroplasts and mitochondria. Under control conditions, the cell walls were smooth and dense (Figure 8a), chloroplasts were well developed and highly stacked (Figure 8a), structures of thylakoid and grana 


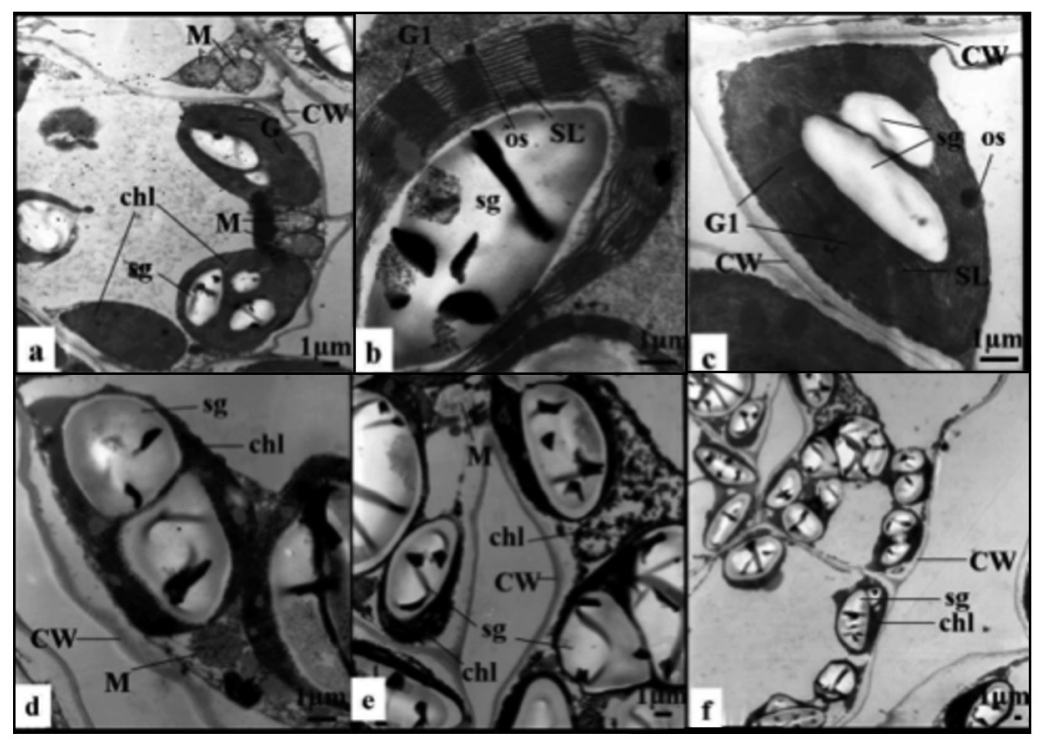

Control group: (a) 4000X, (b) and (c) 12 000X; picloram-treated plants: (d) $12000 \mathrm{X}$, (e) 8000X, (f) 3500X.

Chl: Chloroplast; G: grana; M: mitochondria; sg: starch granules; G1: grana lamella; CW: cell wall; os: osmiophilic granules; SL: stroma lamellae.

Figure 8. Transmission electron micrographs of Eupatorium adenophorum leaf ultrastructure of control plants and after $7 \mathrm{~d}$ exposed to picloram treatments.

lamella were clear and orderly, mitochondria were intact (Figure 8b, c), and osmiophilic granules were fully filled (Figure 8b,c). However, during the period after picloram treatment, chloroplasts were seriously deformed, the thylakoid lamellar structure was destroyed and disorderly (Figure 8d,e,f), and some huge disordered starch granules appeared (Figure 8d, e). In addition, the chemical injury resulted in that mitochondrial membrane in the weed was destroyed; its electron density and osmiophilic granules decreased significantly (Figure 8d).

\section{DISCUSSION}

Plant cell can generate many reactive oxygen species (ROS) in response to stress conditions, such as heavy metal pollution, extreme temperature, drought, saline and herbicides (Pazmiño et al., 2011; Liu et al., 2012; Bhaskaran and Panneerselvam, 2013). If the ROS are not cleared promptly, plasma membranes can be attacked, causing lipid peroxidation and substantial leakage of electrolytes and small organic molecules, damaging the membrane system, causing disorder in various metabolic processes and damage to plant physiological processes (Semane et al., 2007). To prevent such damage to cells, the antioxidant enzyme system is activated or increased to clear the reactive oxygen species (Xu and Huang, 2004).

Previous studies have demonstrated that plant cell membrane play an important role in maintaining the cellular microenvironment and normal metabolism. Under normal conditions the cell membrane has good selectivity. However, when plants are subjected to adverse stress the cell membrane becomes damaged, cell membrane permeability is increased, and electrolyte leakage and conductivity is increased. The level of plasma membrane permeability has a close relationship with stress strength (Tang et al., 2008). MDA is a product of membrane lipid peroxidation and a marker of the degree of cell membrane damage, research has found a positive correlation between MDA content and the degree of membrane lipid peroxide (Corbineau et al., 2002). The results of this study showed that RL and MDA increased with time and with increasing doses of picloram. Both low and high doses of picloram resulted in RL and MDA levels that were high dosage than the control; RL alone showed a slight decrease at $7^{\text {th }}$ day. This was identical to results of (Zhang et al. 2009) on the impacts of acid rain on E. adenophorum and from (Zhai et al. 2009) on the influence of herbicide on Amazon sword. Under picloram stress, the cell membrane structure of E. adenophorum was seriously damaged; its ROS led to metabolic disequilibrium and caused membrane lipid peroxidation, thus causing cell inclusion disclose and a large increase in MDA.

Other studies have observed that, under adverse stress, free proline is substantially produced by plants as an osmotic adjustment substance. It can reduce the damage to cell, and can improve cytosol concentration and reduce water potential when plants are being stimulated; meanwhile free proline accumulation also increased markedly (Zhao and Li, 2001; Hong and Wu, 2008). In our study on E. adenophorum, free proline increased significantly with increased dose during the early stage of picloram stress. However, after $5 \mathrm{~d}$ the free proline content declined and reached a minimum level at $7^{\text {th }}$ day. The results indicated that physiological regulation of $E$. 
adenophorum may resist herbicide injury during the initial stage, but several days later the injury appeared to rise beyond its tolerance ability, the cells metabolism became disordered, and the free proline content creased instead. The reason may be due to weaker stress resistance to picloram. In this study, after low dose herbicide treatment, the soluble protein synthesis was not inhibited during the earlier stage. However, after long stress, under high doses picloram, soluble protein synthesis showed significant inhibition. The results were consistent with previous literature in Liang's study on Zoysia japonica Steud. (Liang et al., 2004), but not in agreement with Chen's research on lawn pennywort (Chen and Sun, 2002). This may result from low dose picloram having stronger activities for obtain auxin, promoting growth of tissues in vitro, and accelerating new protein synthesis (Jurado et al., 2011; Alayón-Luaces et al., 2012). In addition, previous studies have shown that high dose picloram can inhibit the synthesis of $\alpha$-amylase and protein hydrolase (Nelson and Lym, 2003). Thus, because of the inhibition of high doses picloram, the soluble protein of E. adenophorum was reduced significantly.

Plants can produce a large number of free radicals $\left(\mathrm{O}^{2-}\right.$, $\mathrm{OH}^{-}$, and $\mathrm{H}_{2} \mathrm{O}_{2}$ ) under adverse stress conditions. Because of their strong oxidative power, the excess free radicals can damage the organism; they can also attack nucleic acids, proteins amino acids and lipids, leading to cell damage and even to death (Luna et al., 1994). Meanwhile, the activity of anti-oxidation protective enzymes increases rapidly to clear up free radicals, greatly reducing the damage of cells (Yang and Gao, 2001). CAT, SOD, and POD are major protective enzymes of plant antioxidant enzyme systems (Luna et al., 1994). They can form an effective active oxygen radical scavenging system, providing one important material basis for plants to tolerate stress. In this experiment, under low dose picloram stress at the earlier stage, CAT and POD activity increased with increasing reactive oxygen species, indicating that free radical scavenging relies on increasing antioxidant enzyme activity, to some extent relieving the injury due to membrane lipid peroxidation. However, with increasing herbicide concentration and stress period, the stress levels exceeded the plant defense limit, with the result that CAT and POD then decreased significantly. This phenomenon was related to a previous study where picloram was able to chelate free or bonding metal ions (such as $\mathrm{Fe}^{2+}, \mathrm{Cu}^{2+}$, and $\mathrm{Mn}^{2+}$ ) in the plant, leading to inhibition of CAT and POD protein synthesis (Owens, 1969). This caused an obvious accumulation of free radicals and severe damage to plant structure, and finally the induced protective effect gradually disappeared (Xu et al., 2004). Therefore the efficacy of picloram on E. adenophorum is related to its inhibition of CAT and POD activity.

This study demonstrated that chloroplast and mitochondria ultrastructure of E. adenophorum were significantly affected by picloram. The chloroplast is an organelle specialized for carrying out photosynthesis in plants. Following picloram treatment, chloroplasts became seriously damaged, photosynthetic efficiency was reduced significantly, and physiological metabolism became disordered, eventually leading to the death of plants. As one of the most important cellular organelles, mitochondria are the power stations of cells, and their physiological activities are the basis of plant adaptation to the environment (Huang et al., 2001). Previous studies have shown that picloram can inhibit ATP-induced contraction of mitochondrion (Leasure, 1964), and experiments had also confirmed that mitochondrial were substantially destroyed seriously; therefore mitochondrial damage was one of the main causes of death.

\section{CONCLUSION}

In this study, we found that in the initial period of low concentration picloram stress, Eupatorium adenophorum can improve its herbicide-tolerance by increasing the antioxidative system activities; however, with an increase in stress (due to time or high dose) this protective function disappeared. We also found that E. adenophorum exhibits different adaptive responses to low and high picloram concentrations, and that the resulting ultrastructural change was an important cause of death.

\section{ACKNOWLEDGEMENTS}

This investigation was financially supported by the Special Fund for Agro-scientific Research in the Public Interest (nr 201103027) of China, the Construct Program of the Key Discipline in Hunan Province (2011-76), and the Science and Technology Innovative Research Team in Higher Educational Institutions of Hunan Province (2012-318).

\section{LITERATURE CITED}

Aebi, H. 1984. Catalase in vitro. Methods in Enzymology 105:121126.

Alayón-Luaces, P., N. Ponce, L.A. Mroginski, C. Stortz, and G. Sozzi. 2012. Compositional changes in cell wall polysaccharides from apple fruit callus cultures modulated by different plant growth regulators. Plant Science 185:169-175.

Beauchamp, C., and I. Fridovich. 1971. Superoxide dismutase: improved assays and an assay applicable to acrylamide gels. Analytical Biochemistry 44:276-287.

Bhaskaran, J., and R. Panneerselvam. 2013. Accelerated reactive oxygen scavenging system and membrane integrity of two Panicum species varying in salt tolerance. Cell Biochemistry and Biophysics 67:1-8.

Cao, A.C., C.H. Rui, M.X. Guo, C.H. Rui, H.Z. Yuan, D.B. Yang, et al. 2006. Chemical control of Eupatorium adenophorum Spreng. and the effect on the ecological recovery. Journal of Safety and Environment 6:80-85. (in Chinese)

Corbineau, F., C. Gay Mathieu, D. Vinel, and D. Come. 2002. Decrease in sunflower (Helianthus annuus) seed viability caused by high temperature as related to energy metabolism, membrane damage and lipid composition. Physiologia Plantarum 116:489496. 
Chang, I.K., and C.L. Foy. 1982. Complex formation of picloram and related chemicals with metal ions. Pesticide Biochemistry and Physiology 18:141-149.

Chen, P., and Q.Z. Sun. 2002. Effects of 2,4-D and MCPA on some physiological characteristics of lawn Pennywort in the turf of Manila grass. Grassland of China 24:37-40 (in Chinese).

Dos Santos, L.B., and J.C. Masini. 2007. Determination of picloram in natural waters employing sequential injection square wave voltammetry using the hanging mercury drop electrode. Talanta 72:1023-1029.

Foy, C.L., and D. Penner. 1965. Effect of inhibitors and herbicides on tricarboxylic acid cycle substrate oxidation by isolated cucumber mitochondria. Weeds 13:226-231.

Hong, H., and N.B. Wu. 2008. Effects of herbicide on PK activity and physiology indexes of Alternanthera philoxeroides Griseb. Journal of Southwest China Normal University (Natural Science Edition) 33:112-116 (in Chinese).

Huang, Z.W., M. Peng, G. Chen, and P. Shi. 2001. An anatomical study on the leaf structure of salinized wetland Chenopodium glaucum of Qinghai Lake. Acta Botanica Boreali-Occidentalia Sinica 21:1199-1203 (in Chinese)

Jurado, A., M. Fernandes, R. Videira, F. Peixoto, and J. Vicente. 2011. Herbicides: the face and the reverse of the coin. An in vitro approach to the toxicity of herbicides in non-target organisms. $p$ 1-44. In A. Kortekamp (ed.) Herbicides and environment. InTech Europe, Rijeka, Croatia.

Lagrimini, L.M. 1991. Wound-induced deposition of polyphenols in transgenic plants overexpressing peroxidase. Plant Physiology 96:577-583.

Leasure, J.K. 1964. Bioassay methods for 4-amino-3,5,6trichloropicolinic acid. Weeds 12:232-233.

Li, H.S. 2002. Plant Physiology \& Biochemistry: A laboratory manual. p. 164-167. Higher Education Press, Beijing, China (in Chinese)

Li, Y.H., Q. Cheng, and H.A. Ya. 2008. Evaluation of Eupatorium adenophorum Spreng control in non-cultivated land with $24 \%$ picloram. Guangxi Plant Protection 21:9-11 (in Chinese).

Liang, J.Y., P. Chen, B.L. Li, and T.Y. Yu. 2004. Effects of Starane on some physiological characteristics of matrella and zoysia Lantai NO.3. Agriculture \& Technology 24:72-74 (in Chinese).

Liu, N., Z. Lin, and H. Mo. 2012. Metal (Pb, Cd, and Cu)-induced reactive oxygen species accumulations in aerial root cells of the Chinese banyan (Ficus microcarpa). Ecotoxicology 21:2004 2011.

Luna, C.M., C.A. González, and V.S. Trippi. 1994. Oxidative damage caused by an excess of copper in oat leaves. Plant and Cell Physiology 35:11-15.

Manna, P., M. Sinha, and P. Sil. 2006. Aqueous extract of Terminalia arjuna prevents carbon tetrachloride induced hepatic and renal disorders. BMC Complementary and Alternative Medicine 6:33.

Nelson, J.A., and R.G. Lym. 2003. Interactive effects of Aphthona nigriscutis and picloram plus 2,4-D in leafy spurge (Euphorbia esula). Weed Science 51:118-124.

Ortega, Y.K., and D.E. Pearson. 2011. Long-term effects of weed control with picloram along a gradient of spotted knapweed invasion. Rangeland Ecology \& Management 64:67-77.

Owens, L.D. 1969. Toxins in plant disease: Structure and mode of action. Science 165:18-25.
Pazmiño, D.M., M. Rodríguez-Serrano, M.C. Romero-Puertas, A. Archilla-Ruiz, L.D. Del Rio, and L. Sandalio. 2011. Differential response of young and adult leaves to herbicide 2 , 4-dichlorophenoxyacetic acid in pea plants: role of reactive oxygen species. Plant, Cell and Environment 34:1874-1889.

Polle, A., M. Eiblmeier, L. Sheppard, and M. Murray. 1997. Responses of antioxidative enzymes to elevated $\mathrm{CO}_{2}$ in leaves of beech (Fagus sylvatica L.) seedlings grown under a range of nutrient regimes. Plant Cell and Environment 20:1317-1321.

Semane, B., A. Cuypers, K. Smeets, F.V. Belleghem, N. Horemans, H. Schat, et al. 2007. Cadmium responses in Arabidopsis thaliana: glutathione metabolism and antioxidative defence system. Physiologia Plantarum 129:519-528.

Sheley, R.L., T.D. Whitson, V. Carrithers, J.S. Jacobs, and J. Gehrett 2002. Grass response to picloram and clopyralid applied before seeding. Weed Technology 16:645-650.

Smitha, P.D., and A.S. Nair. 2011. Effect of picloram on somatic embryogenesis from leaf-sheath explants in diploid Musa acuminata cv. Njalipoovan. Plant Tissue Culture and Biotechnology 21:83-87.

Song, W.G., L. Zhu, and J.C. Axmacher. 2010. Invasion pattern of Eupatorium adenophorum Spreng. in southern China. Biological Invasions 12:1721-1730.

Tang, X.M., C.F. Gong, and Z.G. Zhou. 2008. Effect of cadmium on root morphology and partial physiological indexes of Solanum nigrum L. Ecology and Environment 17:1462-1465 (in Chinese).

Wei, H.P., M. Zhao, Y. Yan, Y. Li, H.B. Han, and Y. Zheng. 2011. Content determination of $\beta$-element in different parts of Eupatorium adenophorum Spreng. Medicinal Plant 2(12):17-19.

Xu, Q., and B. Huang. 2004. Antioxidant metabolism associated with summer leaf senescence and turf quality decline for creeping bentgrass. Crop Science 44:553-560.

Xu, K.Y., W.H. Ye, X.W. Duan, X.G. Su, and Z.F. Xu. 2004 Physiological adaptation of Alternanthera philoxeroides under water stress condition induced by polyethylene glycol. Journal of Zhejiang University Agriculture and Life Sciences 30:271-277 (in Chinese).

Yang, S.S., and J.F. Gao. 2001. Influence of active oxygen and free radicals on plant senescence. Acta Botanica Boreali-Occidentalia Sinica 21:215-220 (in Chinese).

Zhai, S.M., H.J. Liu, and X.P. Wang. 2009. Physiological characters of Echinodorus amazonicus under stress of two different kinds of herbicide. Chinese Agricultural Science Bulletin 231-235 (in Chinese)

Zhang, F.D., T.L. Li, and D. Wu. 2005. Application technique of control Eupatorium odoratum L. with glyphosate and 2,4 D butylaet. Chinese Journal of Pesticides 44:565-566, 572 (in Chinese).

Zhang, W., Z. Liao, J. Zhu, H. Qiu, and G. Yao. 2009. The physiological changes of Eupatorium adenophorum Spreng under simulated acid rain stress. Forestry Science \& Technology 4:18-21 (in Chinese).

Zhao, X., and Y.L. Li. 2001. Variation of several physiological indices of five cool season turfgrasses under high temperature stress. Acta Pratacultural Sinica 10:85-91 (in Chinese).

Zheng, Y.L., Y.L. Feng, W.X. Liu, and Z.Y. Liao. 2009. Growth, biomass allocation, morphology, and photosynthesis of invasive Eupatorium adenophorum and its native congeners grown at four irradiances. Plant Ecology 203:263-271. 